\title{
Bis-benzylidine Piperidone RA190 treatment of hepatocellular carcinoma via binding RPN13 and inhibiting NF-KB signaling
}

Ruey-Shyang Soong ${ }^{1,2,3}$, Ravi K. Anchoori ${ }^{4}$, Richard B. S. Roden ${ }^{5}$, Rou-Ling Cho ${ }^{3}$, Yi-Chan Chen ${ }^{1}$, Sheng-Chieh Tseng ${ }^{3}$, Yun-Li Huang ${ }^{3}$, Po-Cheng Liao ${ }^{3}$ and Yu-Chiau Shyu U, $^{3,7^{*}}$ (D)

\begin{abstract}
Background: According to GLOBOSCAN, hepatocellular carcinoma (HCC) claimed 782,000 lives in 2018. The tyrosine kinase inhibitor sofafenib is used to treat HCC, but new anticancer agents targeting different pathways are urgently needed to improve outcomes for patients with advanced disease. The aberrant metabolism and aggressive growth of cancer cells can render them particularly susceptible to proteasome inhibition, as demonstrated by bortezomib treatment of multiple myeloma. However, resistance does emerge, and this 205 proteasome inhibitor has not proven active against HCC. The bis-benzylidine piperidone RA190 represents a novel class of proteasome inhibitor that covalently binds to cysteine 88 of RPN13, an ubiquitin receptor subunit of the proteasome's 195 regulatory particle. RA190 treatment inhibits proteasome function, causing rapid accumulation of polyubiquitinated proteins. Considerable evidence suggests that nuclear factor $\mathrm{KB}$ (NF-KB) signaling, which is dependent upon the proteasome, is a major driver of inflammation-associated cancers, including HCC.
\end{abstract}

Methods: Human HCC cell lines were treated with titrations of RA190. The time course of endoplasmic reticulum stress and NF-kB-related mechanisms by which RA190 may trigger apoptosis were assessed. The therapeutic activity of RA190 was also determined in an orthotopic HCC xenograft mouse model.

Results: RA190 is toxic to HCC cells and synergizes with sofafenib. RA190 triggers rapid accumulation of polyubiquitinated proteins, unresolved endoplasmic reticulum stress, and cell death via apoptosis. RA190 blocks proteasomal degradation of $\mathrm{I} \mathrm{KBa}$ and consequent release of NF-KB into the nuclei of HCC cells. Treatment of mice bearing an orthotopic HCC model with RA190 significantly reduced tumor growth.

Conclusions: RA190 has therapeutic activity in a xenograft model, and with sorafenib exhibited synergetic killing of HCC cells in vitro, suggesting further exploration of such a combination treatment of HCC is warranted.

Keywords: Apoptosis, Hepatocellular carcinoma, NF-kB, Proteasome inhibitor, RA190

\footnotetext{
* Correspondence: yuchiaushyu@gmail.com

${ }^{3}$ Community Medicine Research Center, Keelung Chang Gung Memorial

Hospital, No.200, Ln 208, Jijin 1st Rd, Anle Dist, 204, Keelung City, Taiwan,

R.O.C

${ }^{6}$ Department of Nursing, Chang Gung University of Science and Technology,

Taoyuan, Taiwan

Full list of author information is available at the end of the article
}

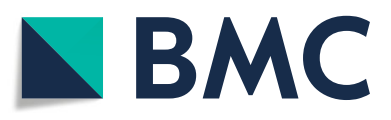

(- The Author(s). 2020 Open Access This article is licensed under a Creative Commons Attribution 4.0 International License, which permits use, sharing, adaptation, distribution and reproduction in any medium or format, as long as you give appropriate credit to the original author(s) and the source, provide a link to the Creative Commons licence, and indicate if changes were made. The images or other third party material in this article are included in the article's Creative Commons licence, unless indicated otherwise in a credit line to the material. If material is not included in the article's Creative Commons licence and your intended use is not permitted by statutory regulation or exceeds the permitted use, you will need to obtain permission directly from the copyright holder. To view a copy of this licence, visit http://creativecommons.org/licenses/by/4.0/. The Creative Commons Public Domain Dedication waiver (http://creativecommons.org/publicdomain/zero/1.0/) applies to the data made available in this article, unless otherwise stated in a credit line to the data. 


\section{Background}

Hepatocellular carcinoma (HCC) is the fifth most common malignancy and the third leading cause of cancer mortality worldwide [1]. The Barcelona Clinic Liver Cancer Staging (BCLC) treatment guidelines recommend surgical resection, liver transplantation, or radio frequency ablation for the management of early stage of HCC, whereas transarterial chemoembolization or systemic chemotherapy are used for patients with intermediate or advanced stage HCC [2]. Systemic chemotherapy for $\mathrm{HCC}$ is limited to only a few conventional drugs (Sorafenib [3, 4], regorafenib [5], lenvatinib, cabozantinib and ramucirumab) with unsatisfactory objective response rates $[6,7]$. These drugs target multiple tyrosine kinase pathways with the exception of ramucirumab that targets VEGF-R2. Even immunotherapy (nivolumab) targeting programmed cell death protein-1 (PD-1) exhibits only a $15-20 \%$ objective response rate in advanced HCC [8]. Thus, new anticancer agents with a distinct mechanism of action are urgently needed to improve outcomes for advanced HCC patients.

The ubiquitin-proteasome system (UPS) is a complex and tightly controlled system that mediates protein homeostasis by degrading $80-90 \%$ of cellular proteins and it is central to regulating key cellular functions through targeted protein degradation. The high metabolic and protein synthesis rates that sustain the aggressive growth of cancer cells place increased burden on the UPS, thereby creating a therapeutic window. Furthermore, several driver oncogenic pathways are dependent on the UPS to mediate signaling, providing further rationale to UPS inhibition as cancer therapy [9]. Indeed, the $20 \mathrm{~S}$ proteasome subunit has been validated as a therapeutic target in cancer by the licensure of three PSMB5-targeted inhibitors, beginning in 2003 with bortezomib for the treatment of multiple myeloma. Recently, accumulating evidence suggests that small molecules targeting alternative components of the UPS, including the receptors for its ubiquitinated substrates, also have potential for the treatment of HCC [10].

The bis-benzylidine piperidone RA190 covalently binds to cysteine 88 of RPN13 (also called ADRM1), a key ubiquitin receptor in the $19 \mathrm{~S}$ regulatory particle of the proteasome, and inhibits its function causing rapid accumulation of polyubiquitinated proteins. RA190 showed a therapeutic effect in multiple myeloma, cholangiocarcinoma [11], ovarian and cervical cancer models in previous studies [12]. In this study, we examine the impact of RA190 on HCC cells, including the levels of polyubiquitinated proteins, Endoplasmic Reticulum (ER) stress, apoptosis, and its therapeutic potential against an orthotopic xenograft model. Since the tyrosine kinase inhibitor sorafenib is used to treat $\mathrm{HCC}$, we also examine whether combining RA190 with sorafenib has a synergistic antitumor effect, given their distinct mechanisms of action.

Nuclear factor $\kappa B(N F-\kappa B)$ is important for promoting inflammation-associated cancer [13, 14]. Its activation triggers the transcription of numerous genes with $\kappa B$ binding sites, most of them are involved in the regulation of inflammation, immune responses and cell survival [15]. I $\mathrm{I} B \alpha$ is the most prominent $I \kappa B$ family member bound to NF- $\mathrm{B}$, restricting it to the cytoplasm and thereby inhibiting its activity. Phosphorylation of I $\mathrm{B} \alpha$ by the IKK complex at two different serine residues (Ser32 and Ser36) marks $I_{\kappa} B \alpha$ for subsequent degradation through an ubiquitin-dependent pathway in the proteasome, thereby liberating NF- $\mathrm{B}$ for nuclear entry, DNA-binding and transcriptional activation [16]. Inhibition of $\mathrm{I} \kappa \mathrm{B} \alpha$ degradation by proteasome inhibitors prevents the release and nuclear entry of NF-kB. RA190 was previously reported to block NF- $\mathrm{B}$ signaling via stabilization of $\mathrm{p}-\mathrm{I} \kappa \mathrm{B} \alpha[11,12]$. Here, we examine whether RA190 inhibits the NF- $\mathrm{B}$ pathway by preventing $I_{\kappa} B \alpha$ degradation by the proteasome, causing the cytoplasmic accumulation of NF- $\mathrm{B}$ in HCC cells.

\section{Methods \\ Cell lines}

HepG2, human hepatocellular carcinoma cell lines were purchased from Bioresource Collection and Resource Center (BCRC numbers RM60025 and 60,434), Taiwan and were grown in DMEM medium (Gibco) supplemented with $10 \%$ FBS (Gibco), $100 \mu \mathrm{g} / \mathrm{mL}$ penicillin (Gibco), and $100 \mathrm{U} / \mathrm{mL}$ streptomycin (Gibco).

\section{Animal}

Mouse experiments were conducted with the prior ethics approval from Animal Care and Use Committee in Chang Gung Memorial Hospital, Keelung. Male nude mice CAnN.Cg-Foxn1nu/CrlNarl (4-6 weeks old, $20 \mathrm{~g}$ ) were purchased from the National Laboratory Animal Center (Taipei, Taiwan). All mice were sacrificed by using $\mathrm{CO}_{2}$ for $20 \mathrm{~min}$. All animal procedures were conducted in Abnova Company and were performed according to approved protocols and by recommendations for the proper use and care of laboratory animals.

\section{Chemicals}

RA190 and RA190B were synthesized in-house and purified to $99 \%$ as previously described [12]. Sorafenib and bortezomib were purchased from L.C. laboratories.

\section{qRT-PCR}

Total RNA was isolated from cells using the RNeasy mini kit (Qiagen). Extracted RNA was normalized for concentration and reverse transcribed using iScript cDNA synthesis kit (Bio-Rad). Taqman gene expression 
assays measured Bip-1, ATF-4, CHOP10, RPN13, iNOS, GAPDH expression levels utilizing Taqman gene expression master mix (Applied Biosystems) per the manufacturer's instructions. Spliced XBP1 mRNA was assayed with SsoFast ${ }^{\text {ti }}$ EvaGreen ${ }^{\bullet}$ Supermix (Bio-rad) following the recommendations for the iCycler System. Forward and reverse primer was: 5'-TGCTGAGTCCGCAGCAGGTG and 5'-TGGGTCCAAGTTGTCCAG AATGCC. Calculations were done according to the Livak method and normalized to reference gene GAPDH. Each condition was replicated three times; each sample was run in triplicate. $2 \mu \mathrm{L}$ cDNA sample was used for PCR amplification with $\mathrm{iQ}^{\mathrm{Tm}} \mathrm{SYBR}^{\circ}$ Green Supermix (Bio-Rad) according to the manufacturer's protocol.

\section{Biotin labeling assay}

HepG2 cells $\left(5 \times 10^{6}\right)$ were lysed using MPER (Pierce) lysis buffer $(1 \mathrm{~mL})$ according to the manufacturer protocol. Cell lysates were centrifuged at 10,000 rpm briefly ( $2 \mathrm{~min}$ ) at $4{ }^{\circ} \mathrm{C}$ to remove cell debris. Lysate supernatant $(100 \mu \mathrm{L})$ was pre-cleared with streptavidin dyna beads $(20 \mu \mathrm{L})$ for 1 hour at $4{ }^{\circ} \mathrm{C}$ to remove non-specific biotin binding and incubated with compounds (indicated concentrations) at $4{ }^{\circ} \mathrm{C}$ for $1 \mathrm{~h}$. An equal amount of each sample $(20 \mu \mathrm{L}$ of lysate) was mixed with the same volume of Laemmli sample buffer $(20 \mu \mathrm{L})$ (BioRad) and was boiled for $5 \mathrm{~min}$. The proteins were separated using 4-15\% Bio-Rad Mini-PROTEAN SDS-PAGE gel (1 h at $100 \mathrm{~V}$ ) and transferred to the membrane overnight at $4{ }^{\circ} \mathrm{C}(24 \mathrm{~V})$. The membrane was blocked with $5 \%$ BSA in PBST (phosphate buffered saline containing 0.1\% Tween 20) for $1 \mathrm{~h}$ at room temperature and washed for $20 \mathrm{~min}$ (3X in PBST). Then the membrane was probed with HRP-streptavidin (1:10,000 in PBST) for $1 \mathrm{~h}$ at room temperature and soaked for $30 \mathrm{~min}$ ( $3 \mathrm{X}$ in PBST) and developed using HyGLO chemiluminescent detection reagent (Denville) for biotin recognition.

\section{Western blot analysis}

$50 \mu \mathrm{g} /$ well of protein from the HepG2 cell lysate was separate using SDS-PAGE and transferred to a nitrocellulose membrane (G.E. Bioscience). After blocking with $5 \%$ skim milk in PBST for $1 \mathrm{~h}$ at room temperature, membranes were incubated overnight with primary antibody at $4{ }^{\circ} \mathrm{C}$. Layers were then washed with PBST and incubated with horseradish peroxidase (HRP)-conjugated secondary antibody before visualization with ECL plus (G.E. Bioscience). All antibodies, including NF- $\mathrm{kB}$ (Cell signaling D14E12, \#Cat.8242), ІкB $\alpha$ (Cell signaling L35A5, \#Cat. 4814), poly-Ub (Enzo FK2, \#Cat. BMLPW0150-0100), P21 (Cell Signaling 12D1, \#Cat 2947), Actin (Abcam EPR16769, \#Cat. Ab179467), lamin A (Abcam EPR4068, \#Cat. ab108922), and tubulin (Abcam EPR13796, \#Cat. ab210797) were diluted in 5\% BSA buffer. The dilution ratio of each antibody followed the manufacturer's recommendation.

\section{Clonogenicity assay}

Clonogenicity assays were performed as previously described [17]. Briefly, HepG2 cells (500 cells/well) were plated in a 6-well plate at day 1 . Cells were treated on day 2 with RA190 at the indicated concentrations. After 14-days incubation, colonies were stained with crystal violet $(0.5 \% \mathrm{w} / \mathrm{v})$ and imaged. The intensity of the signals were quantified by Image J software V1.50f (National Institutes of Health).

\section{Immunofluorescence stain}

$1.5 \times 10^{4}$ cells of HEpG2 per well were seeded in the 8chamber slide in $500 \mu \mathrm{L}$ of culture medium, incubated at $37^{\circ} \mathrm{C}$ under humidified $95 \%$ air $/ 5 \% \mathrm{CO}_{2}$ for $18 \mathrm{~h}$. After treatment for $30 \mathrm{~min}$, the slides were fixed with $4 \%$ paraformaldehyde (in PBS pH 7.4) for $10 \mathrm{~min}$, and permeabilized with $400 \mu \mathrm{L}$ of $0.1 \%$ Triton X100 in 1X PBS at room temperature for $5 \mathrm{~min}$. After blocking with $3 \mathrm{~mL}$ $10 \%$ donkey serum in PBS pH 7.4 at R.T. $30 \mathrm{~min}$, the slides were incubated overnight with the primary antibody, ІкB $\alpha$ (Cell Signaling, \#Cat. 4812S), NF-кB (B.D., \#Cat 558,393) and proteasome (PSMD2 19S RP subunit (NOVUS, \#Cat. NB100-1483)) at $4{ }^{\circ} \mathrm{C}$. After washing slides with PBST pH 7.4, secondary Ab was added (antiRabbit-Alexa488 (Invitrogen, \#Cat. 412,438), anti-GoatDyLight650 (Bethyl, \#Cat. A50-200D5) and proteasomeanti-Mouse-Alexa546 (Invitrogen, \#Cat. 412,438)) in 1\% donkey serum in PBS pH 7.4 for $2 \mathrm{~h}$. Finally, the nucleus was stained with DAPI (Thermo, \#Cat. D1306) in 1\% donkey serum in PBS pH 7.4 for $10 \mathrm{~min}$, and the slides mounted using antifade. The immunofluorescence signal was visualized by confocal microscopy using a Leica TCS SP8 and edited by Leica LAS X software.

\section{Flow cytometry analysis}

Cell were stained with Annexin V-PE (B.D., \#Cat. 560, 930), propidium iodide (B.D., \#Cat. 556,463), or Active Caspase 3-PE (B.D., \#Cat. 561,011) and flow cytometric analyses performed on a Becton-Dickinson FACScan with CELLQuest software (Becton-Dickinson Immunocytometry System, Mountain View, CA) and Flowjo 10 software.

\section{Orthotopic tumor implantation model}

Male nude mice, 4-6 weeks old, were anesthetized via i.p. administration of $80 \mathrm{mg} / \mathrm{kg}$ ketamine and $10 \mathrm{mg} / \mathrm{kg}$ xylazine. While under demonstrable anesthesia, an upper midline incision of the abdomen was made and $5 \times 10^{5}$ HepG2-Luc cells mixed with Matrigel (1:1) in $20 \mu \mathrm{L}$ was injected into the left lobe of the liver through a 23-gauge syringe by laparotomy, six in each group. To avoid the 
leakage of the tumor and seeding into the peritoneum, the injection site was compressed by cotton swab for 2 min until no bleeding was evident from the liver surface [18]. After tumor injection, the abdominal wound was closed by interrupted stitches afterward afforded analgesia. To monitor the tumor growth in mice, the tumor was imaged by the IVIS system as previously described [19].

\section{Statistical analysis}

All data are expressed as mean \pm S.E. where indicated and are representative of at least two separate experiments. In the tumor treatment experiments, the outcome of interest was the volume of the tumor estimated using calipers until euthanasia based on the animal protocol (in stress, weight change greater than 20\%). The tumor volumes were compared using ANOVA at each time point. All $p$-values $<0.05$ were considered significant. The statistics were calculated by Prism 6 software.

\section{Results \\ RA190 exhibits more potent HepG2 cell killing than sorafenib}

HepG2 cells were seeded at a density of 2500 cells/well in $100 \mu \mathrm{L}$ DMEM medium supplemented with $10 \%$ FBS in 96-well plate. Twenty-four hours post seeding, the cells were treated with RA190 and sorafenib at specified concentrations. Seventy-two hours after treatment, cells were incubated according to the manufacturer's protocol with the MTT reagent for $1 \mathrm{~h}$, and absorbance at 570 $\mathrm{nm}$ measured to assess inhibition of cell growth. The $\mathrm{IC}_{50}$ for RA190 of $0.15 \mu \mathrm{M}$ was significantly lower than for sorafenib $(9.7 \mu \mathrm{M})$ against HepG2 cells (Fig. 1a). In a clonogenicity assay, HepG2 cells treated with RA190 exhibited a reduced number of tumor colonies with an $\mathrm{IC}_{50}$ of $0.1 \mu \mathrm{M}$ (Fig. 1b).

\section{RA190 triggers rapid accumulation of polyubiquitinated proteins}

Since RA190 is a 19S RP-targeted proteasome inhibitor [12], we examined its impact on the levels of polyubiquitinated proteins in HepG2 cells by ubiquitin immunoblot analysis. RA190 treatment of HepG2 cells for $12 \mathrm{~h}$ at $1 \mu \mathrm{M}$ or $2 \mu \mathrm{M}$ dramatically increased the levels of polyubiquitinated proteins and in a dose-dependent manner (Fig. 1c and d). We also observed a significant increase in insoluble polyubiquinated cellular proteins in the lysates removed by high speed centrifuging before loading into the gel. This likely accounts for the reduction in ubiquitinated protein observed by Western blot when treating with higher doses of RA190 (lane 3 versus lane 2). Because RPN13 also acts to promote UCH37's deubiquitinase function, the molecular weight of the accumulated polyubiquitinated proteins observed following exposure to RA190 was higher than seen in bortezomib-treated cells, as previously described [20].

\section{RA190 binds to RPN13 in HepG2 cells}

To identify RA190's cellular target in HepG2 cells, biotin was covalently linked to RA190 via its free amine functionality (RA190B), as previously described [12]. HepG2 cell lysate was treated with RA190B (at 0, 5, 10, or $25 \mu \mathrm{M})$, subjected to SDS-PAGE, and probed with streptavidin-peroxidase following protein transfer to a polyvinylidene difluoride (PVDF) membrane. The streptavidin-peroxidase bound to biotinylated cellular proteins and a new band at $42 \mathrm{kDa}$ was found in treated samples (Fig. 2a) that is consistent with the molecular weight of RPN13 and our previous data in other cancer cell lines [12]. In addition, mRNA collected from HepG2 cells was treated with RA190 at either 0 or $2 \mu \mathrm{M}$ for 0 , 4,15 , or $24 \mathrm{~h}$, was subjected to quantitative RT-PCR with primers specific for $A D R M 1$, the gene encoding RPN13, and the housekeeping gene GAPDH. The $A D R M 1$ mRNA expression was significantly increased by RA190 treatment (Fig. 2b) relative to the housekeeping gene. Taken together, the results suggest that RA190 binds to and the $42 \mathrm{kDa}$ RPN13 protein in HepG2 cells, triggering compensatory upregulation of $A D R M 1$.

\section{Rapid accumulation of polyubiquitinated proteins leads to ER stress and apoptosis}

In addition to the rapid accumulation of polyubiquitinated unfolded proteins, RA190 treatment also triggered the elevation of BIP-1, ATF-4,CHOP10 and spliced $X B P-1$ transcript expression levels (Figs. 3a-d), consistent with an ER stress response. At later time points after RA190 treatment, HepG2 cells also exhibited a significantly increased the proportion of Annexin V/PI double positive cells (Figs. $4 \mathrm{a}-\mathrm{c}$ ), suggesting activation of apoptosis because of an unresolved ubiquitin proteasome stress response. Indeed, caspase 3 (Fig. 4c) and PARP (Fig. 1c) cleavage and p21 expression (Fig. 1d) were also considerably increased in HepG2 cells after RA190 treatment, providing further biochemical evidence of the activation of apoptosis.

Autophagy is a potentially compensatory pathway to mitigate the impact of proteasome inhibition. Formation of the lipidated LC3-II, a biomarker of autophagy, was not elevated within $8 \mathrm{~h}$ after RA190 $2 \mu \mathrm{M}$ treatment (Fig. $\mathrm{S} 1$ ), although this was seen upon addition of $10 \mu \mathrm{M}$ chloroquine, a positive control. Taking together, the rapid accumulation of polyubiquitinated proteins after RA190 treatment caused ER stress that could not be counteracted by the induction of autophagy, leading to apoptosis of the HepG2 cells. 


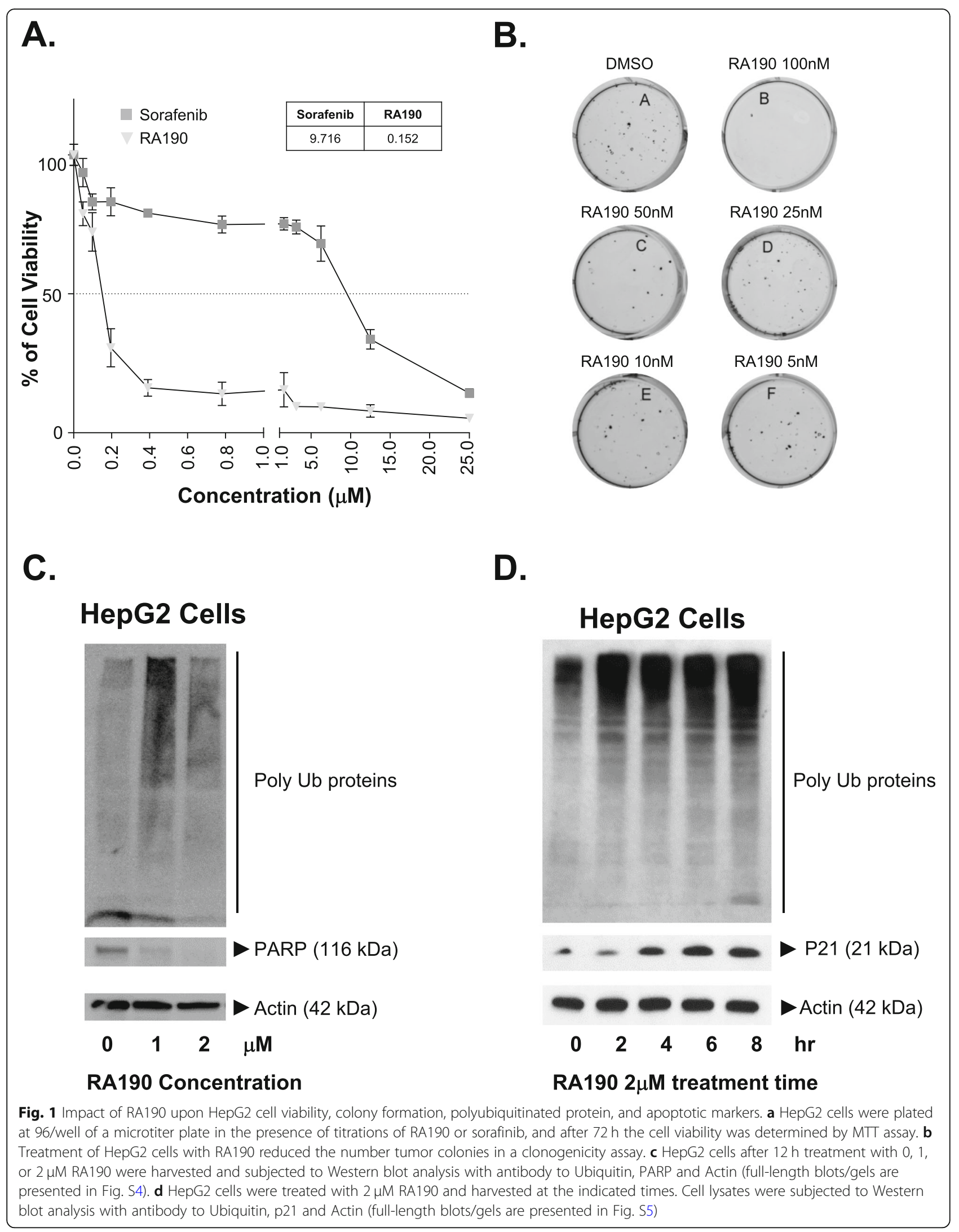


A.

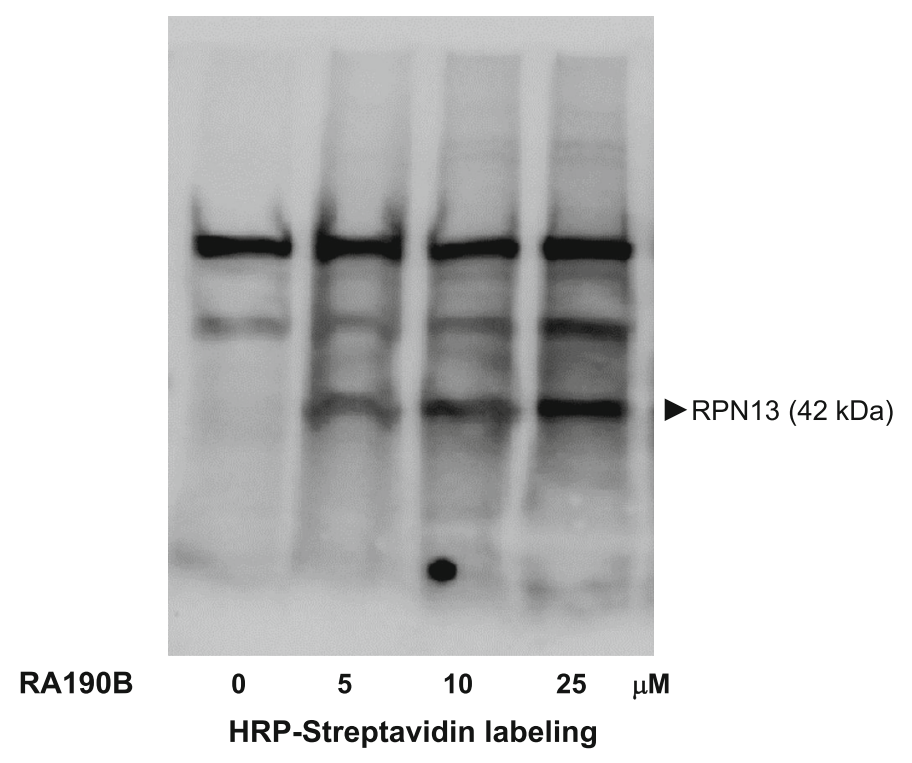

B.

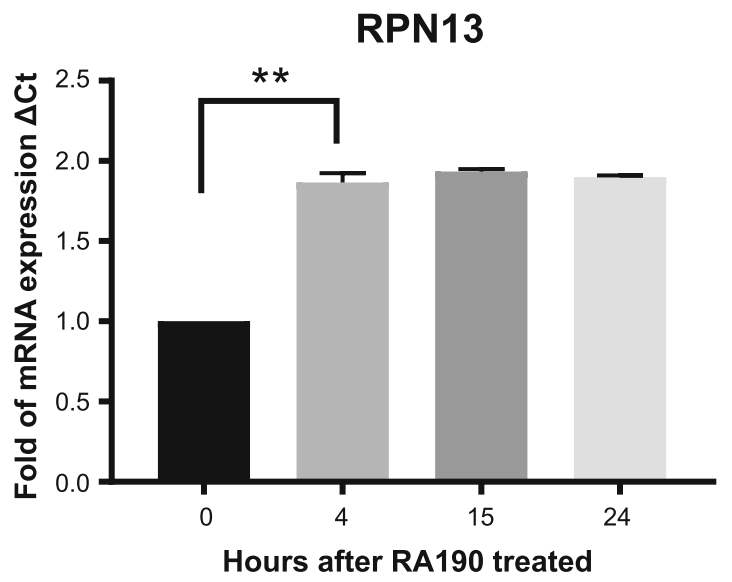

Fig. 2 RA190B binds to RPN13 in HepG2 cells. a HepG2 cell lysates were incubated with 0, 5, 10 or 25 HM RA190B, separated by SDA-PAGE, transferred to a membrane and probed with HRP-streptavidin. After development using chemiluminescence, a prominent band at $42 \mathrm{KDa}$ was evident, a molecular weight consistent with RPN13 (full-length blots/gels are presented in Fig. S6). b RPN13 (ADRM1) mRNA expression as determined by quantitative RT-PCR was significantly increased after $4 \mathrm{~h}$ RA190 treatment

RA190 blocks IKBa degradation and limits NF-KB entry to the nucleus

To examine whether RA190 blocked IkB $\alpha$ degradation and thereby the entry of NF- $\mathrm{kB}$ to the nucleus, we used immunofluorescence to visualize $I \kappa B \alpha$ and NF- $\kappa B$ at 30 min after treating with RA190 or the $20 \mathrm{~S}$ proteasome inhibitor MG132 (which has a similar action as bortezomib) as compared to DMSO (vehicle)-treated cells. IкB $\alpha$ was readily detectable in the cytoplasm of RA190 or
MG132-treated cells (Fig. 5 and Fig. S2). In the DMSO

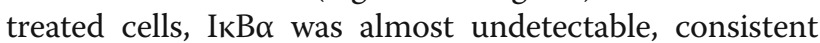
with its rapid degradation by the proteasome. Most of the IkB $\alpha$ is co-located with the proteasome (Fig. 5b) in RA190 or MG132-treated cells. In the DMSO-treated group, the majority NF-kB protein was nuclear. While much was still in the nucleus, the NF- $\mathrm{kB}$ protein was significantly increased in the cytoplasm in the RA190 treated group (Fig. 5c), likely reflecting the short 
A.

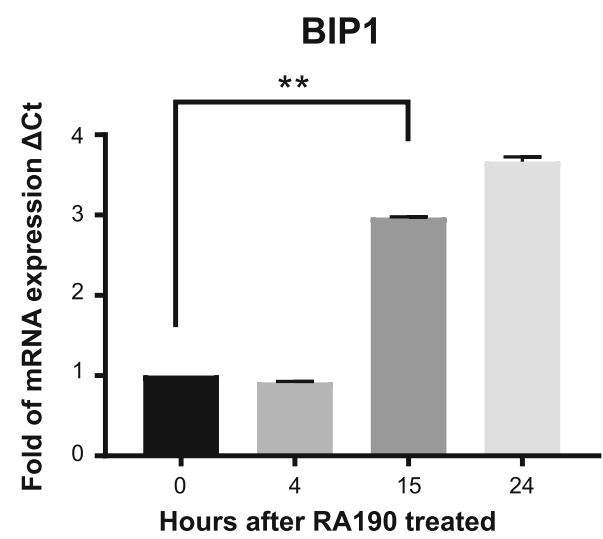

C.

CHOP10

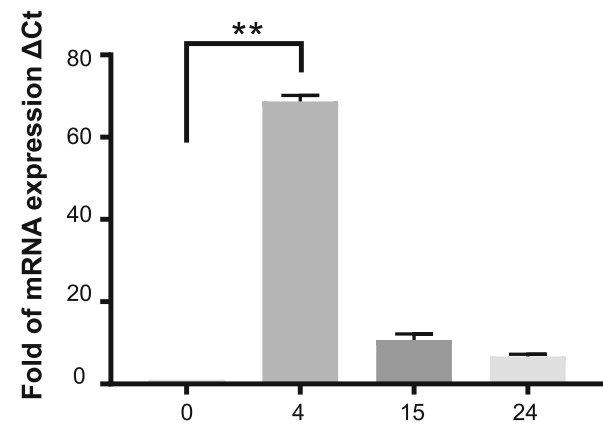

Hours after RA190 treated
B.

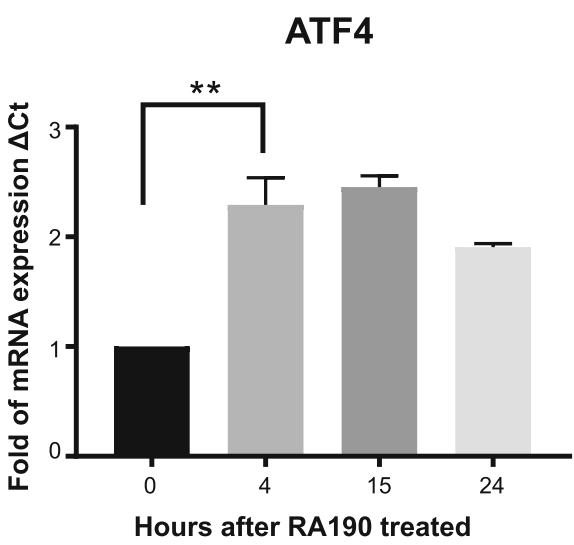

D.

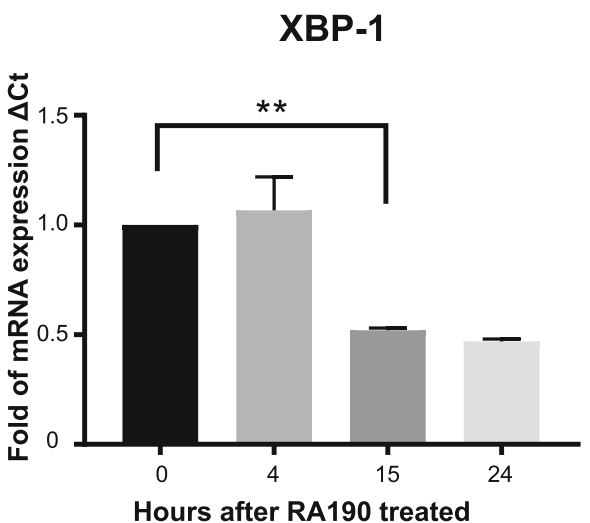

Fig. 3 Elevation of mRNA levels of UPR genes after RA190 treatment. $\mathbf{a}, \mathbf{b}, \mathbf{c}$, $\mathbf{d}$ The mRNA expression levels of ER stress proteins BIP-1, ATF-4, CHOP10, and spliced XBP-1 were determined by quantitative RT-PCR in HepG2 cells 0, 4, 15 and $24 \mathrm{~h}$ after $2 \mu \mathrm{M}$ RA190 treatment

incubation period. The $I \kappa B \alpha$ signal intensity in the cytoplasm and nuclei was quantified by Image J software and this analysis showed the fraction in the cytoplasm was significantly higher in RA190-treated group (Fig. 5f). Likewise, the percentage of NF- $\mathrm{B}$ signal intensity in cytoplasm was also higher in RA190-treated group (Fig. $5 \mathrm{~g})$. This result was also examined $60 \mathrm{~min}$ post-treatment by immunoblot of the cytoplasmic vs. nuclear cellular factions, and a similar pattern was observed (Fig. 6). The NF- $\kappa B$ was significantly accumulated in the cytoplasm at $60 \mathrm{~min}$ after RA190 treatment (Fig. 6a-b), and a similar finding was evident in MG132-treated HepG2 cells (Fig. 6c-d). The levels of phosphorylated and ubiquitinated $\mathrm{I}_{\kappa} \mathrm{B} \alpha$ also built up after RA190 and bortezomib treatment (Fig. S3). When considered together, these observations suggest RA190 prevents $\mathrm{I} \kappa \mathrm{B} \alpha$ degradation by the proteasome.

\section{RA190 treatment inhibits growth of an orthotopic HCC} xenograft model

HepG2-Luc cells $\left(5 \times 10^{5}\right.$ cells in $\left.20 \mu \mathrm{L}\right)$ were injected into the left lobe of the liver at day 0 . Once the tumor signal was detected at day 7 upon i.p. injection of luciferin and IVIS imaging, the mice were randomized into two groups (6 mice in each group). Upon randomization, treatment (RA190 $20 \mathrm{mg} / \mathrm{kg}$ in the active arm, and DMSO in the control arm, intraperitoneal injection) was initiated once daily for 21 days. The tumor was visualized and bioluminescence quantified after injection of luciferin by the IVIS imaging system again at day 11, 14, 21, 28, 35 and 42. Two mice in the DMSO group were sacrificed early due to tumor burden at day 35 . Surviving mice in both groups were sacrificed at day 42 and the tumor volume was smaller in the liver specimen of the RA190-treated mice (Fig. 7a). Figure 7b shows the signal 
A.

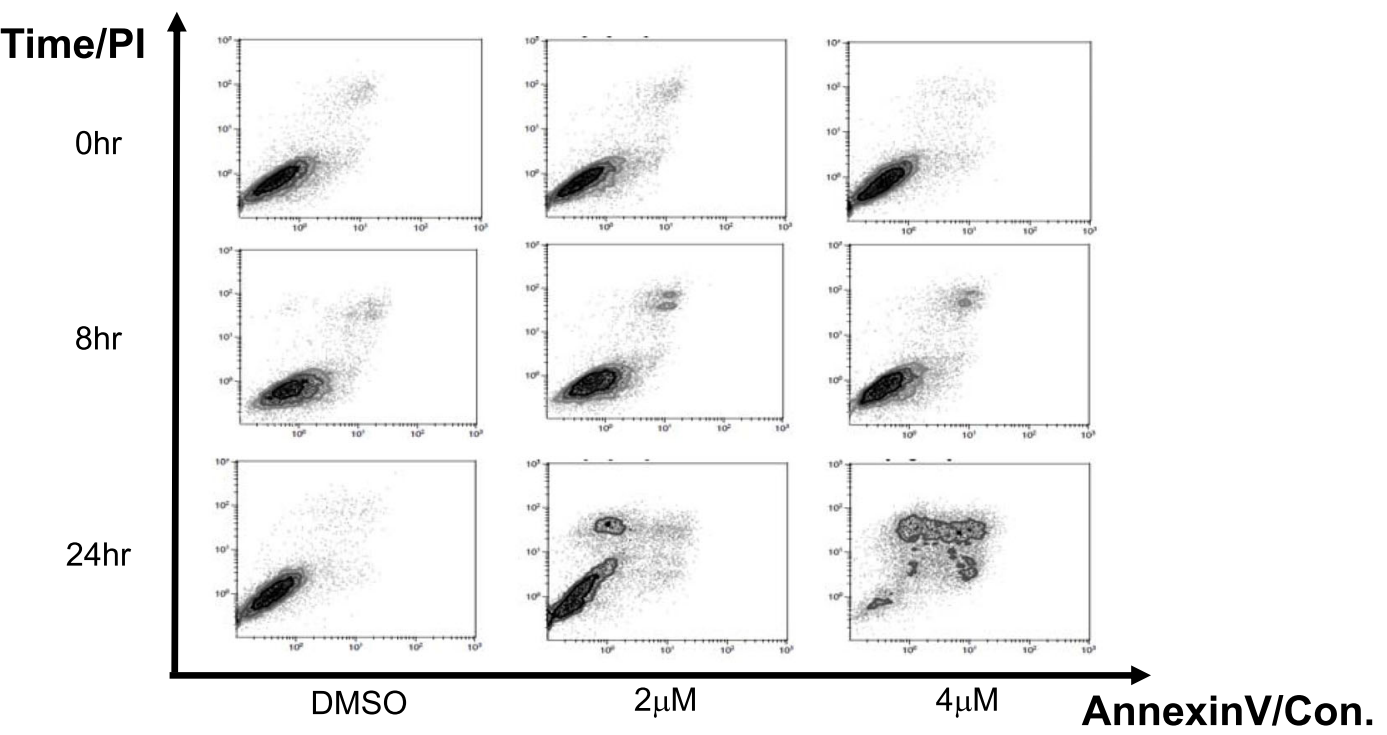

B.

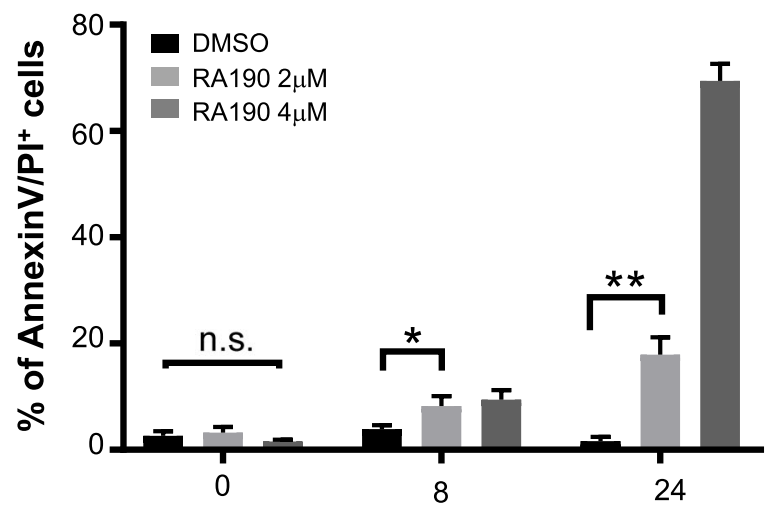

Hours after RA190 treated

C.

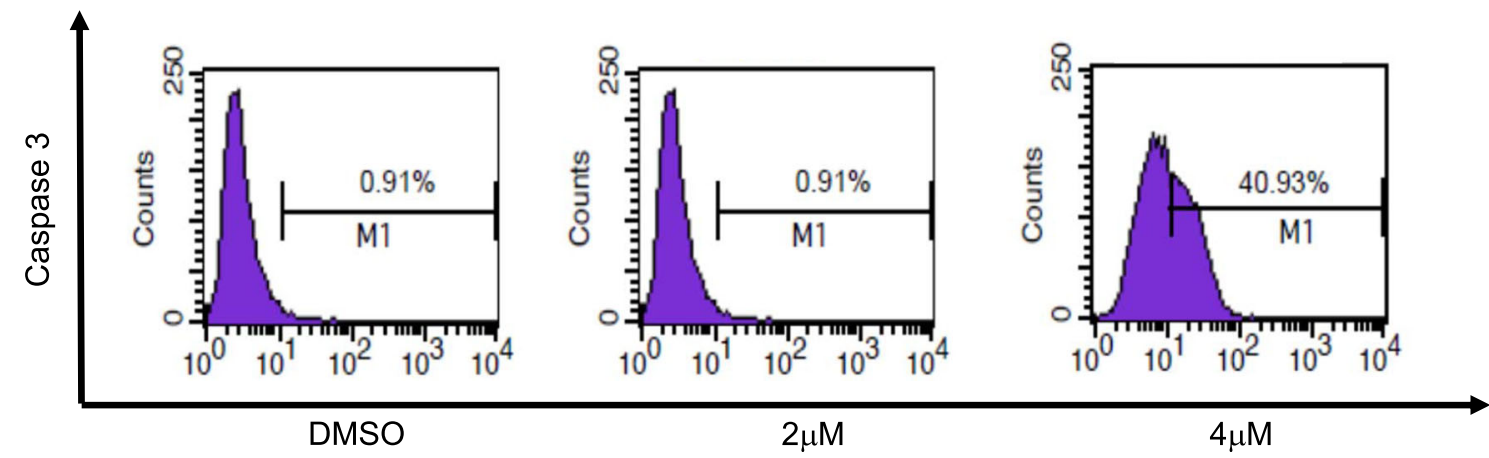

Fig. 4 RA190 triggers apoptosis in HepG2 cells. a, b The percentage of $\mathrm{Pl}^{+} / A n n e x i n \mathrm{~V}^{+}$HepG2 cells was determined by flow cytometry after treatment with 0, 2 or $4 \mu \mathrm{M}$ RA190 for 0, 8 or 24 h. c Active Caspase 3 level was determined by flow cytometry after treatment with 0, 2 or $4 \mu \mathrm{M}$ RA190 for $8 \mathrm{~h}$ 


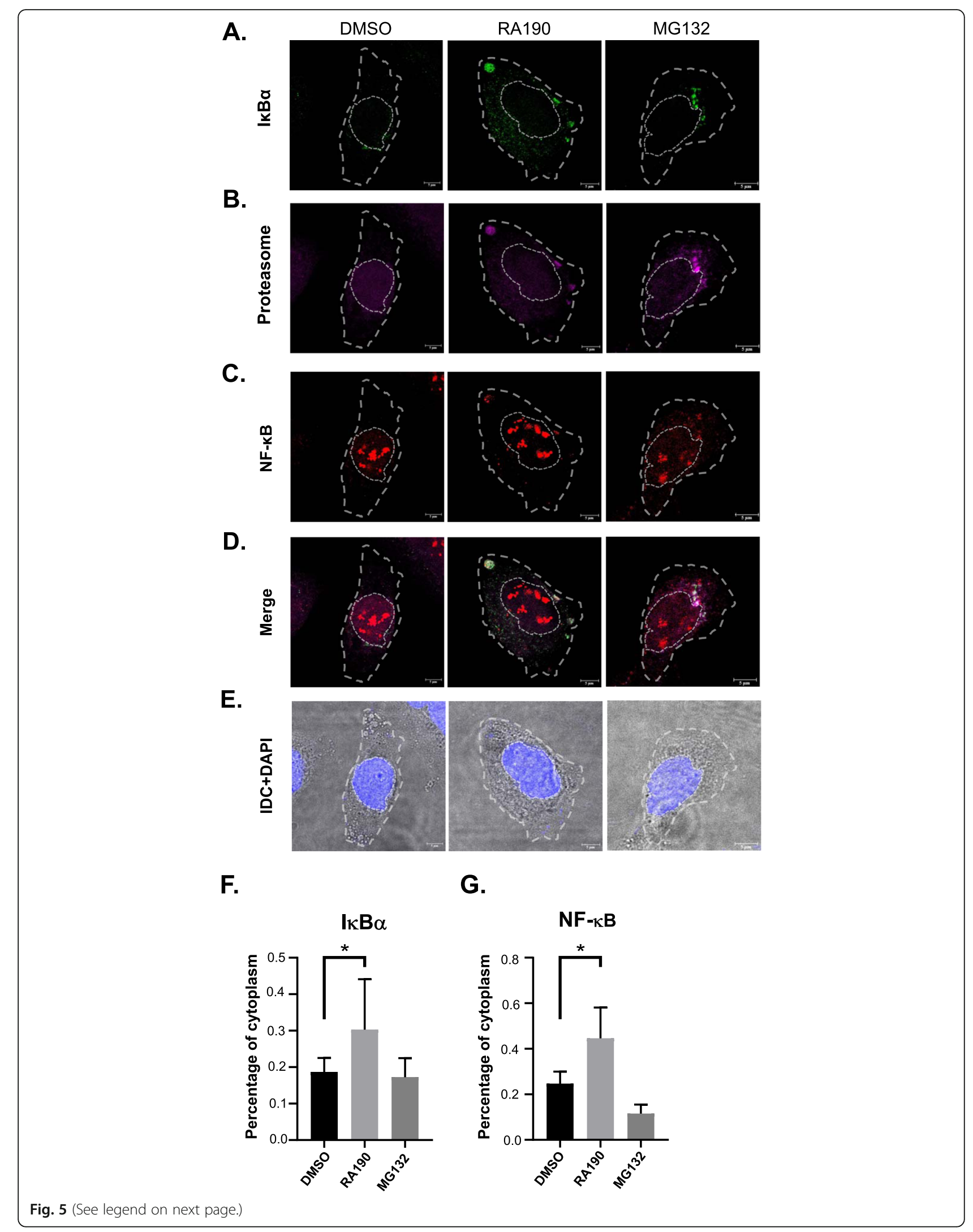


(See figure on previous page.)

Fig. 5 RA190 causes accumulation of IKBa and NF-KB in the cytoplasm, co-localized with proteasomes. HepG2 cells were treated with DMSO, $2 \mu \mathrm{M}$ RA190 for or $25 \mu \mathrm{M}$ MG132 for $30 \mathrm{~min}$. The cells were fixed, permeabilized and stained for $1 \mathrm{~KB}$ a $\mathbf{a}$, proteasome $\mathbf{b}$, NF-KB $\mathbf{c}$ and viewed by confocal fluorescence microscopy individually, or $\mathbf{d}$ merged, or e under phase contrast. $\mathbf{a}, \mathbf{b}, \mathbf{c}$ ।kBa and NF-kB in RA190 and MG132-treated cells is significantly accumulated in cytoplasm, and apparently co-localized with the proteasome. The proportion of fluorescence in the cytoplasm versus the nucleus was quantified for $\mathbf{f} \mid \mathrm{kBa}$, or $\mathbf{g} \mathrm{NF}-\mathrm{KB}$

change in individual mice. The bioluminescence intensity in RA190 groups was significantly lower than the DMSO group $(P=0.02)$ at day 35 time point.

\section{RA190 and Sorafenib combination is synergistic}

Synergistic combinations of multiple drug treatments targeting different pathways have proven most effective to treat cancer and stave off the emergence of resistance. Zero interaction potency (ZIP) score is an approach used to assess synergy and it captures the drug interaction relationships by comparing the change in the potency of the dose-response curves between individual drugs and their combinations [21]. To test whether combination treatment might have a synergetic killing effect for HCC, we reduced the RA190 concentration to $1 \mu \mathrm{M}$ and Sorafenib to $10 \mu \mathrm{M}$. After treating $18 \mathrm{~h}$, cell viability was still around $80 \%$ with individual drugs. However, combining RA190 and Sorafenib, significantly improved the killing effect and cell viability dropped lower than 40\% (Fig. 8a). The optimal combination ratios were further sought using a checkerboard analysis to assess cell viability with titrations of RA190 and sofeninib, and analyzing the data using the ZIP synergy score prediction model with the Synergy Finder application. In this experiment HepG2 cells were first treated with Sorafenib and $48 \mathrm{~h}$ later with RA190 (for the final $24 \mathrm{~h}$ ) for a total assay time of $72 \mathrm{~h}$. A ZIP synergy score of 2.31 was achieved, which indicates a synergetic effect (Fig. 8b, c) [21].

\section{Discussion}

The ubiquitin-proteasome pathway is a central component in maintaining protein homeostasis. The increased metabolism of cancer cells is associated with aberrant protein expression, including the accumulation of misfolded or deleterious proteins. This proteotoxic stress renders cancer cells more reliant upon proteasome function to degrade the over-produced/mis-folded protein accumulation, thereby creating a therapeutic window and providing a rationale for proteasome inhibition as a means to shift this delicate equilibrium towards cell death [22]. Proteasome inhibitors have also been examined as potential HCC therapy, and while some preclinical studies showed promising results [23], unfortunately, clinical responses have been less encouraging $[24,25]$. This may reflect limited uptake of the licensed proteasome inhibitors by solid HCC tumors, suggesting that testing alternative small molecule proteasome inhibitors is warranted.

NF- $\mathrm{kB}$ acts as a central link between hepatic injury, fibrosis, and HCC, and it likely represents an important target for the treatment of liver fibrosis and/or HCC [13]. The activation of NF- $\kappa B$ drives transcription of hundreds of genes with $\mathrm{kB}$ binding sites that are involved in the regulation of inflammation, immune responses and cell survival [15]. NF- $\mathrm{kB}$ is held in an inactive cytoplasmic complex with an inhibitory I $k B$ protein. To activate NF- $\kappa B$, the phosphorylated I $\kappa \mathrm{B} \alpha$ is detached from the NF- $\mathrm{kB}$ complex and transferred to the proteasome for degradation. The malfunction of IкB $\alpha$ is an important driver of aberrant constitutive NF- $\mathrm{kB}$ in solid tumors [26], including HCC [14]. NF- $\mathrm{kB}$ activity is dependent on the RPN13-UCH37 axis in the proteasome because it contributes to the recognition of polyUbtagged IкB $\alpha$ as a substrate for the proteasome. Removal of the polyUb tag (deubiquitination) occurs ahead of substrate transfer to the catalytic subunit for degradation. Upon substrate recognition, RPN13 activates the deubiquitinase function of its binding partner UCH37. Therefore, inhibiting RPN13 function blocks both substrate recognition and deubiquitination activity, and this has been shown critical for NF-kB activation via RPN13 knockdown and RPN13 inhibitors such as RA183 and RA190 [27].

Overexpression of ADRM1 mRNA and /or RPN13 was reported in many types of malignancy, including multiple myeloma, diffuse large B-cell lymphoma, gastric cancer, ovarian cancer, and intrahepatic cholangiocarcinoma and high expression of RPN13 correlated with poor prognosis [11]. The overexpression of ADRM1 mRNA and RPN13 was detected in HCC, and NF-kB activity was reduced therein by knockdown of ADRM1/ RPN13 [28]. We further observed that RA190 inhibited I $B \alpha$ protein degradation and led to the accumulation of $\mathrm{I} \mathrm{KB} \alpha$ coincident with the proteasome (Fig. $5 \mathrm{a}, \mathrm{b}$ ), consistent with a role for RPN13 in control of NF-kB activity. Indeed, RA190 limits nuclear entry of NF- $\mathrm{B}$ (Fig. 4c, Fig. 5) and inhibition of this pathway likely contributes to HCC cell death. Indeed, we found that RA190 treatment exerted a significant therapeutic effect on an orthotopic HCC xenograft model, as seen in other cancer types [12]. Consistent with an on-target effect, biotinylated RA190 also bound with specificity to the 42 kDa RPN13 in HepG2 cells. RA190 treatment also led to 
A.

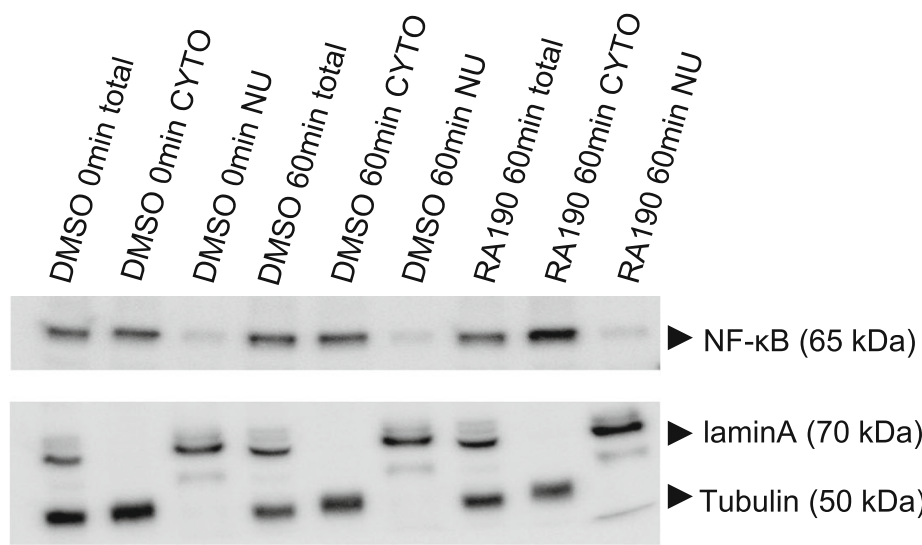

C.
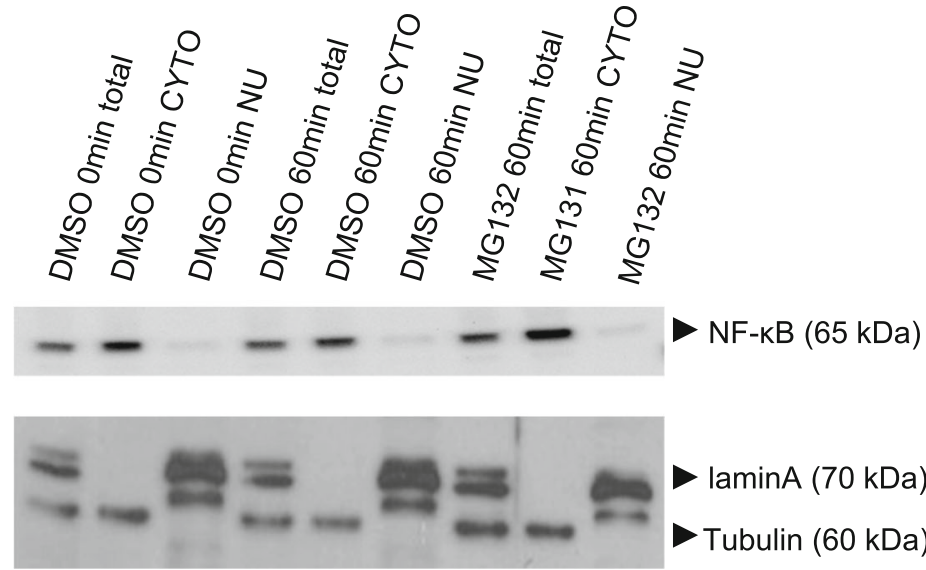

Fig. 6 (See legend on next page.)
B.


D.
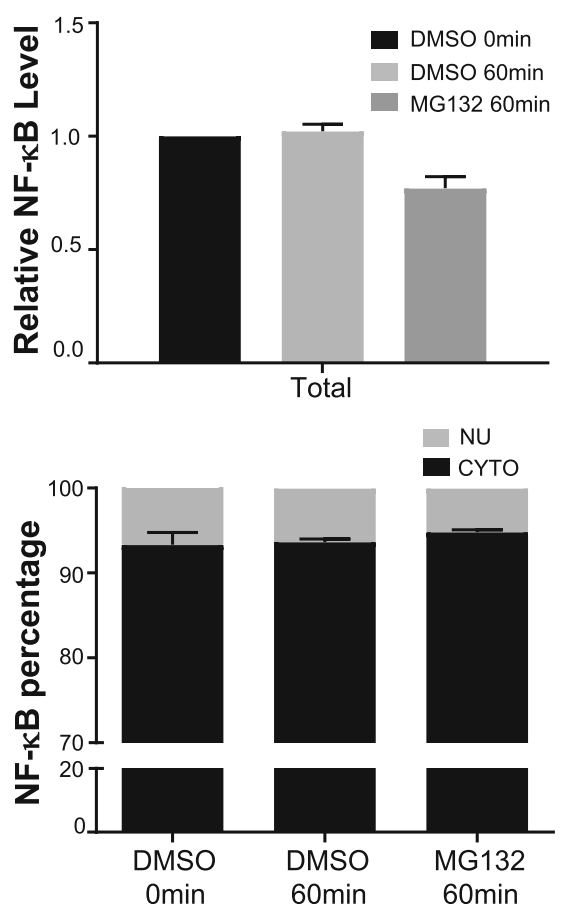
(See figure on previous page.)

Fig. $6 \mathrm{NF}-\mathrm{KB}$ is significantly accumulated in the cytoplasmic fraction after RA190 treatment. HepG2 cells were treated with DMSO or $2 \mu \mathrm{M}$ RA190 for $60 \mathrm{~min}$, harvested and lysed (total fraction). Cytoplasmic and nuclear fractions were separated, and each fraction was subjected to Western blot with antibody to NF-kB, lamin a (a nuclear marker) and tubulin (a cytoplasmic marker). a NF-KB showed significant accumulation in the cytoplasmic fraction of cells when treated with RA190 for $60 \mathrm{~min}$, as compared with DMSO (full-length blots/gels are presented in Fig. S7). The quantified data is presented in a bar graph b. c Similar results were obtained with MG132 treatment (full-length blots/gels are presented in Fig. S8) and the quantification is presented in a bar graph $\mathbf{d}$

the rapid accumulation of poly-ubiquitinated proteins in HCC cells, and initiated apoptosis (Fig. 4) that is consistent with inhibition of proteasome function and unresolved proteotoxic stress. While RPN13 has previously been seen to regulate cisplatin-induced autophagy,
RA190 did not activate the autophagy pathway (Fig. S1) in HCC. While RA190 had a significant tumor control effect in the orthotopic tumor implant model in vivo (Fig. 6), it was not curative. This suggests the need for combination therapy by targeting another independent

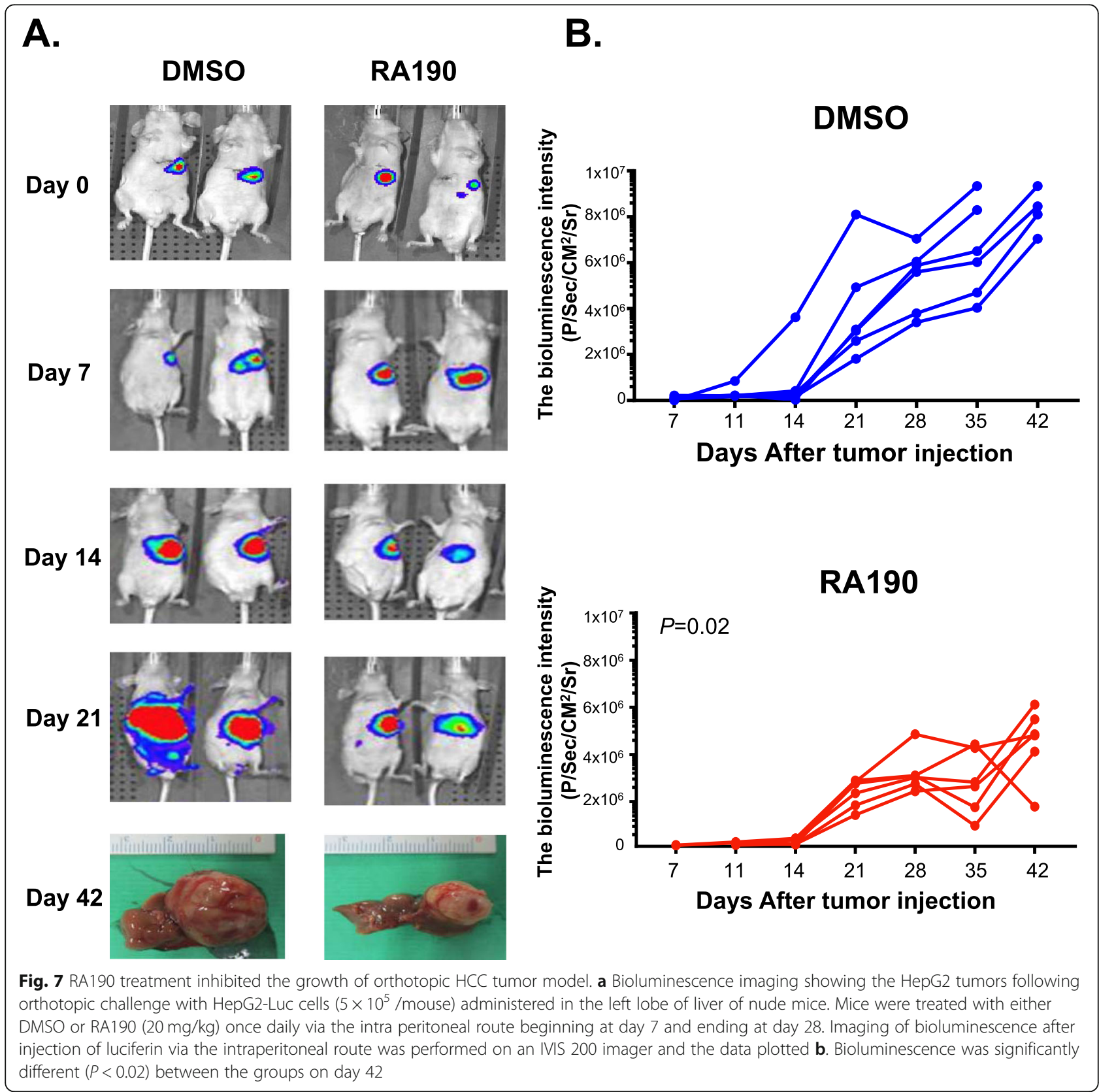


A.

HepG2 $18 \mathrm{hr}$

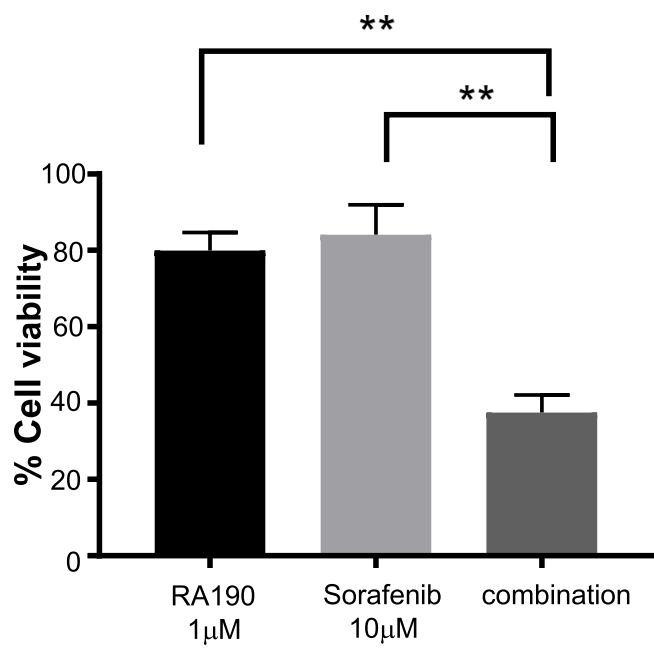

C.

Dose-response curve for drug : RA190

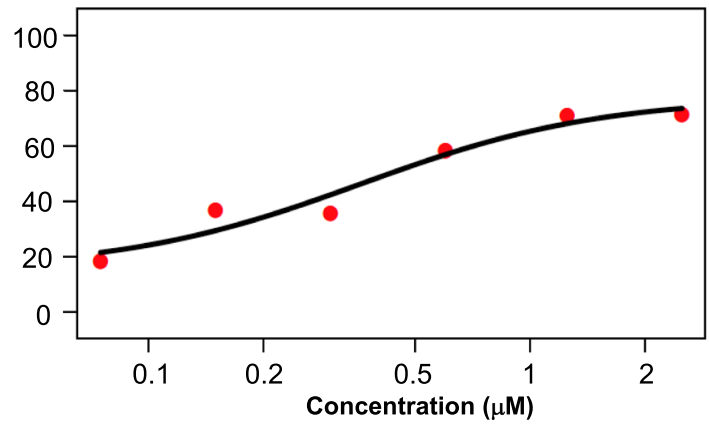

Dose-response curve for drug : Sorafenib

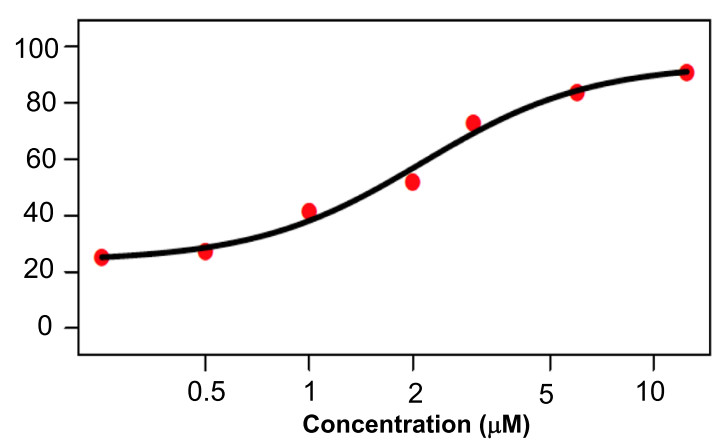

B.

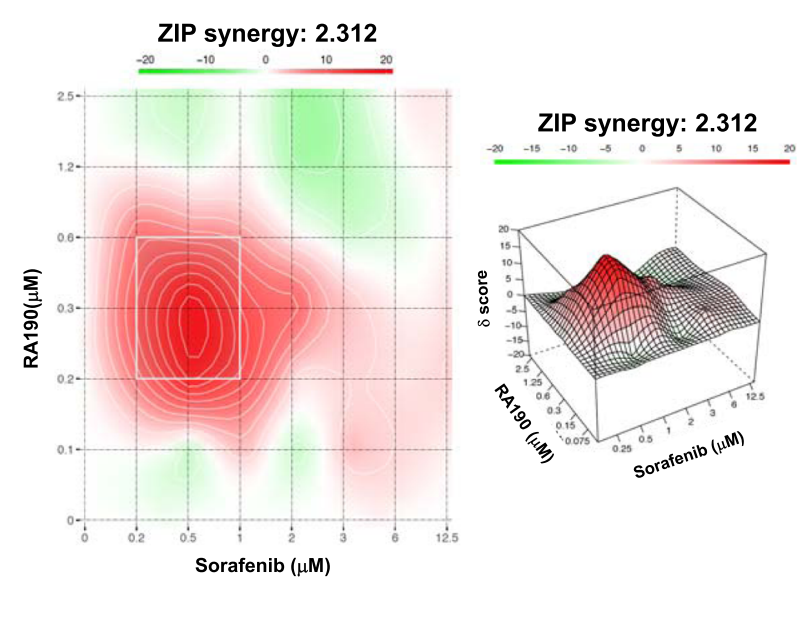

Dose-response matrix (inhibition)

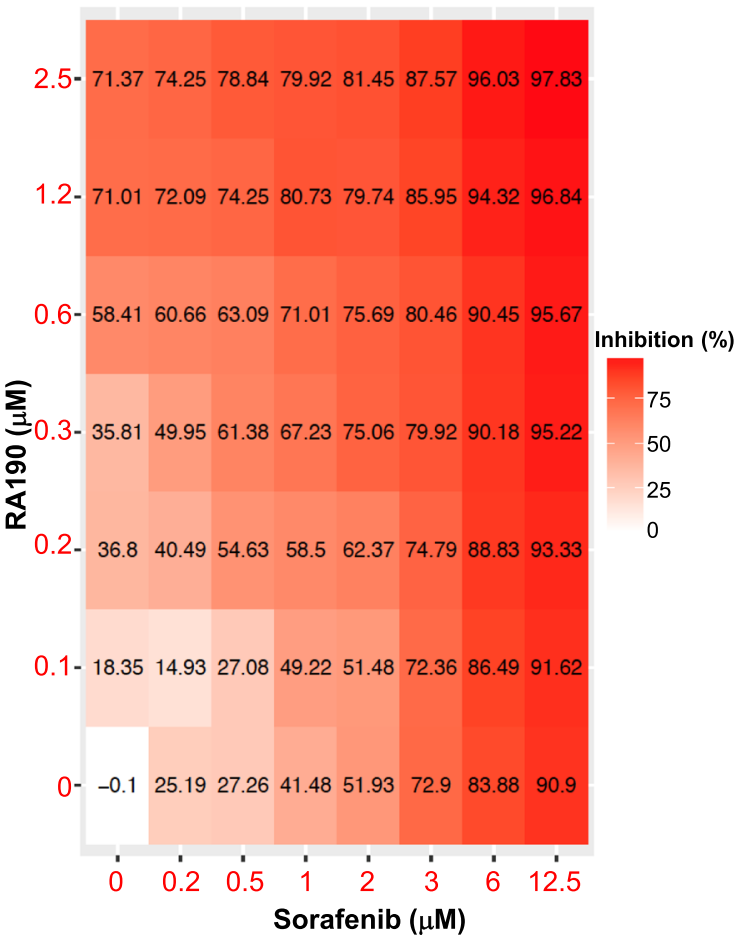

Fig. 8 RA190 combination with Sorafenib showed synergy against HepG2 cells. a Bar graph depicting HepG2 cell viability after $48 \mathrm{~h}$ of each treatment regimen. To seek the conditions of optimal synergy, a checkerboard analysis was performed using titrations of RA190 and Sorafenib. $\mathbf{b}$, c A surface plot of the Synergy score showed the most synergistic cell killing occurred at 0.3 $\mu \mathrm{M}$ RA190 and $0.5 \mathrm{mM}$ Sorafenib 
cell pathway critical to $\mathrm{HCC}$ viability, such as tyrosine kinase signaling. Sorafenib is used clinically to treat HCC, and we observed synergy with RA190 in vitro.

\section{Conclusions}

In summary, RA190 binds to RPN13 in HCC cells and inhibits proteasome function therein. This triggers apoptosis in the HCC cells because of a rapid accumulation of poly-ubiquinated protein accumulation and resultant unresolved endoplasmic reticulum stress, as well as the inhibition of NF- $\mathrm{kB}$, a critical oncogenic signal in HCC, by preventing the degradation of I $\mathrm{KB} \alpha$. While RA190 treatment slowed the growth of an orthotopic HCC xenograft model, synergy seen in studies in vitro suggest that an RPN13 inhibitor like RA190 might fruitfully be combined with sorafenib as a salvage therapy for HCC patients.

\section{Supplementary information}

Supplementary information accompanies this paper at https://doi.org/10. 1186/s12885-020-06896-0.

Additional file 1: Figure S1. RA190 treatment HepG2 cell lines did not activate the autophagy pathway. Figure S2. Immunostaining of NF-KB and IKB after treating with RA190. Figure S3. RA190 treatment of HepG2 cells produced significant accumulation of phosphorylated/ubiquitinated $\mathrm{IKBa}$

Additional file 2: Figure S4. Original images to Fig. 1C. Figure S5. Original images to Fig. 1D. Figure S6. Original images to Fig. 2A. Figure S7. Original images to Fig. 6A. Figure S8. Original images to Fig. 6C. Figure S9. Original images to Fig. S1. Figure S10. Original images to Fig. S3.

\section{Abbreviations}

HCC: Hepatocellular carcinoma; NF-kB: Nuclear factor-kB; BCLC: Barcelona Clinic Liver Cancer Staging; PD-1: Programmed cell death protein-1; UPS: Ubiquitin-proteasome system

\section{Acknowledgments}

We would like to thank Ms. Lin, Shin-Ying of Community Medicine Research Center in Keelung Chang Gung Memorial Hospital for kindly assistance.

\section{Authors' contributions}

Dr. SRS designed the research. Dr. RA created the chemical compound and performed the drug killing assays. Dr. RA analyzed the in vitro assay and biotin labeling assay. Dr. CYC performed the animal study. Mr. TSC perform the clonogenicity assay, immunofluorescence stain and PCR studies. Ms. HYL performed the Western blot experiments. Dr. CRL was a major contributor in statistical analysis. Mr. LPC was a major contributor the figure creation. Drs. SRS, SYC and RR wrote the manuscript. Dr. SYC performed all the research. All authors of the manuscript have read and agreed to its content and are accountable for all aspects of the accuracy and integrity of the manuscript. The author(s) read and approved the final manuscript.

\section{Funding}

This research was funded by Chang Gung Medical Research Grants (CMRPG2H0181, CMRPG2J0341 and CLRPG2J0011). This work was supported in part by grants from the National Institutes of Health grant P50 CA098252, P50CA22899 and P30CA06973, the Alleghany Health Network-Johns Hopkins Cancer Research Fund, and the Ovarian Cancer Research Fund Alliance \#458972 (to RKA and RBSR). The project was also supported in part by the Dr. Richard W. TeLinde endowment. The funding bodies played no role in the design of the study and collection, analysis, and interpretation of data and in writing the manuscript.

\section{Availability of data and materials}

The data generated and analyzed during the current study are not publicly available due to confidentiality requirements but are available from the corresponding author on reasonable request.

\section{Ethics approval and consent to participate}

Mouse experiments were conducted with the ethics approval from Animal Care and Use Committee in Chang Gung Memorial Hospital, Keelung. All animal procedures were performed according to approved protocols and by recommendations for the proper use and care of laboratory animals.

\section{Consent for publication}

Not applicable.

\section{Competing interests}

The authors declare the following competing financial interest(s): Under a licensing agreement between Pontifax/PI Therapeutics and Johns Hopkins University, Drs. Anchoori and Roden are entitled to royalties on an invention (US patent application 20190175572) described in this article. This arrangement has been reviewed and approved by Johns Hopkins University in accordance with its conflict of interest policies. The content is solely the responsibility of the authors and does not necessarily represent the official views of the National Institutes of Health.

\section{Author details}

${ }^{1}$ Department of General Surgery, Keelung Chang Gung Memorial Hospital, Keelung, Taiwan. ${ }^{2}$ Chang Gung Medical College Taoyuan, Taoyuan, Taiwan. ${ }^{3}$ Community Medicine Research Center, Keelung Chang Gung Memorial Hospital, No.200, Ln 208, Jijin 1st Rd, Anle Dist, 204, Keelung City, Taiwan, R.O.C. ${ }^{4}$ Department of Oncology, Johns Hopkins University, Baltimore, MD, USA. ${ }^{5}$ Department of Pathology, Johns Hopkins University, Baltimore, MD, USA. ${ }^{6}$ Department of Nursing, Chang Gung University of Science and Technology, Taoyuan, Taiwan. ${ }^{7}$ Institute of Molecular Biology, Academia Sinica, Taipei, Taiwan.

Received: 6 December 2019 Accepted: 23 April 2020

Published online: 06 May 2020

\section{References}

1. Bray F, Ferlay J, Soerjomataram I, Siegel RL, Torre LA, Jemal A. Global cancer statistics 2018: GLOBOCAN estimates of incidence and mortality worldwide for 36 cancers in 185 countries. CA Cancer J Clin. 2018;68(6):394-424.

2. Liver EAFTSOT. EASL-EORTC clinical practice guidelines: management of hepatocellular carcinoma. J Hepatol. 2012;56(4):908-43.

3. Wilhelm SM, Carter C, Tang L, Wilkie D, McNabola A, Rong H, Chen C, Zhang $X$, et al. BAY 43-9006 exhibits broad spectrum oral antitumor activity and targets the RAF/MEK/ERK pathway and receptor tyrosine kinases involved in tumor progression and angiogenesis. Cancer Res. 2004;64(19): 7099-109.

4. Llovet JM, Ricci S, Mazzaferro V, Hilgard P, Gane E, Blanc JF, de Oliveira AC, Santoro A, et al. Sorafenib in advanced hepatocellular carcinoma. N Engl J Med. 2008;359(4):378-90.

5. Bruix J, Qin S, Merle P, Granito A, Huang YH, Bodoky G, Pracht M, Yokosuka $\mathrm{O}$, et al. Regorafenib for patients with hepatocellular carcinoma who progressed on sorafenib treatment (RESORCE): a randomised, double-blind, placebo-controlled, phase 3 trial. Lancet. 2017;389(10064):56-66.

6. Galle PR, Forner A, Llovet JM, Mazzaferro V, Piscaglia F, Raoul JL, Schirmacher P, Vilgrain V. EASL clinical practice guidelines: management of hepatocellular carcinoma. J Hepatol. 2018.

7. Heimbach JK, Kulik LM, Finn RS, Sirlin CB, Abecassis MM, Roberts LR, Zhu AX, Murad $\mathrm{MH}$, et al. AASLD guidelines for the treatment of hepatocellular carcinoma. Hepatology. 2018;67(1):358-80.

8. El-Khoueiry AB, Sangro B, Yau T, Crocenzi TS, Kudo M, Hsu C, Kim TY, Choo $\mathrm{SP}$, et al. Nivolumab in patients with advanced hepatocellular carcinoma (CheckMate 040): an open-label, non-comparative, phase 1/2 dose escalation and expansion trial. Lancet. 2017;389(10088):2492-502.

9. Bedford L, Lowe J, Dick LR, Mayer RJ, Brownell JE. Ubiquitin-like protein conjugation and the ubiquitin-proteasome system as drug targets. Nat Rev Drug Discov. 2011;10(1):29-46. 
10. Mansour MA, Aljoufi MA, Al-Hosaini K, Al-Rikabi AC, Nagi MN. Possible role of selective, irreversible, proteasome inhibitor (carfilzomib) in the treatment of rat hepatocellular carcinoma. Chem Biol Interact. 2014;215:17-24.

11. Yu GY, Wang X, Zheng SS, Gao XM, Jia QA, Zhu WW, Lu L, Jia H-L, et al. RA190, a proteasome subunit ADRM1 inhibitor, suppresses intrahepatic cholangiocarcinoma by inducing NF-KB-mediated cell apoptosis. Cell Physiol Biochem. 2018;47(3):1152-66.

12. Anchoori RK, Karanam B, Peng S, Wang JW, Jiang R, Tanno T, Orlowski RZ, Matsui W, et al. A bis-benzylidine piperidone targeting proteasome ubiquitin receptor RPN13/ADRM1 as a therapy for cancer. Cancer Cell. 2013; 24(6):791-805.

13. Luedde T, Schwabe RF. NF-kB in the liver-linking injury, fibrosis and hepatocellular carcinoma. Nat Rev Gastroenterol Hepatol. 2011;8(2):108.

14. Pikarsky E, Porat RM, Stein I, Abramovitch R, Amit S, Kasem S, GutkovichPyest E, Urieli-Shoval S, et al. NF-KB functions as a tumour promoter in inflammation-associated cancer. Nature. 2004;431(7007):461.

15. Pahl HL. Activators and target genes of Rel/NF-KB transcription factors. Oncogene. 1999;18(49):6853.

16. Yaron A, Hatzubai A, Davis M, Lavon I, Amit S, Manning AM, Andersen JS, Mann $M$, et al. Identification of the receptor component of the $1 \mathrm{kBa}-$ ubiquitin ligase. Nature. 1998;396(6711):590.

17. Franken NA, Rodermond HM, Stap J, Haveman J, Van Bree C. Clonogenic assay of cells in vitro. Nat Protoc. 2006;1(5):2315.

18. Reiberger T, Chen Y, Ramjiawan RR, Hato T, Fan C, Samuel R, Roberge S, Huang $P$, et al. An orthotopic mouse model of hepatocellular carcinoma with underlying liver cirrhosis. Nat Protoc. 2015;10(8):1264-74.

19. Soong RS, Anchoori RK, Yang B, Yang A, Tseng S, He L, Tsai Y, Roden R, et al. RPN13/ADRM1 inhibitor reverses immunosuppression by myeloidderived suppressor cells. Oncotarget 2016.

20. Lu X, Nowicka U, Sridharan V, Liu F, Randles L, Hymel D, Dyba M, Tarasov SG, et al. Structure of the Rpn13-Rpn2 complex provides insights for Rpn13 and Uch37 as anticancer targets. Nat Commun. 2017;8(1):1-13.

21. Yadav B, Wennerberg K, Aittokallio T, Tang J. Searching for drug synergy in complex dose-response landscapes using an interaction potency model. Comput Structural Biotechnol J. 2015;13:504-13.

22. Manasanch EE, Orlowski RZ. Proteasome inhibitors in cancer therapy. Nat Rev Clin Oncol. 2017;14(7):417.

23. Ganten TM, Koschny R, Haas TL, Sykora J, Li-Weber M, Herzer K, Walczak H. Proteasome inhibition sensitizes hepatocellular carcinoma cells, but not human hepatocytes, to TRAIL. Hepatology. 2005;42(3):588-97.

24. Ciombor KK, Feng Y, Benson AB 3rd, Su Y, Horton L, Short SP, Kauh JS, Staley $\mathrm{C}$, et al. Phase II trial of bortezomib plus doxorubicin in hepatocellular carcinoma (E6202): a trial of the eastern cooperative oncology group. Investig New Drugs. 2014;32(5):1017-27.

25. Kim GP, Mahoney MR, Szydlo D, Mok TS, Marshke R, Holen K, Picus J, Boyer $J$, et al. An international, multicenter phase II trial of bortezomib in patients with hepatocellular carcinoma. Investig New Drugs. 2012;30(1):387-94.

26. Pacifico F, Leonardi A. NF-kB in solid tumors. Biochem Pharmacol. 2006; 72(9):1142-52.

27. Anchoori RK, Jiang R, Peng S, Soong RS, Algethami A, Rudek MA, Anders N, Hung CF, et al. Covalent Rpn13-binding inhibitors for the treatment of ovarian cancer. ACS omega. 2018;3(9):11917-29.

28. Yang X, Miao X, Wen Y, Hu J, Dai W, Yin B. A possible connection between adhesion regulating molecule 1 overexpression and nuclear factor kappa B activity in hepatocarcinogenesis. Oncol Rep. 2012;28(1):283-90.

\section{Publisher's Note}

Springer Nature remains neutral with regard to jurisdictional claims in published maps and institutional affiliations.

Ready to submit your research? Choose BMC and benefit from:
- fast, convenient online submission
- thorough peer review by experienced researchers in your field
- rapid publication on acceptance
- support for research data, including large and complex data types
- gold Open Access which fosters wider collaboration and increased citations
- maximum visibility for your research: over 100M website views per year
At BMC, research is always in progress.
Learn more biomedcentral.com/submissions

